\title{
ANALISIS PENGARUH SUDUT KEMIRINGAN TERHADAP ARUS KELUARAN PADA PHOTOVOLTAIC DENGAN MENGGUNAKAN REGRETION QUADRATIC METHOD
}

\author{
Samsurizal $^{1}$, Andi Makkulau ${ }^{2}$, Christiono ${ }^{3}$ \\ ${ }^{1}$ Teknik Elektro (Sekolah Tinggi Teknik PLN) \\ ${ }^{2}$ Teknik Elektro (Sekolah Tinggi Teknik PLN) \\ ${ }^{3}$ Teknik Elektro (Sekolah Tinggi Teknik PLN) \\ E-mail: samsurizal@sttpln.ac.id
}

\begin{abstract}
Renewable energy sources that have renewable properties and sustainable renewable energy sources are alternatives that need to be developed continuously. Solar Power Plants use solar energy as a renewable source and convert solar energy into electricity. To maximize the sunlight received by solar panels, the system design requires the most appropriate tilt angle to receive the highest solar radiation. This study was conducted to determine the increase in current against changes in the slope angle of the photovoltaic, using the regret quadratic method. The results obtained from the angle of view of $P V$ with outflow using the optimal angle quadratic regression method of solar cells in receiving solar radiation at an angle of $36.7^{\circ}$, with an output current value of 1.99 Ampere. It turned out that the results of the real measurements were compared using quadratic regression methods obtained by the results of the RMSE (root mean sequre error) 0.27476 .
\end{abstract}

Keywords: Photovoltaic, Slope Angle, Quadratic Regression

\begin{abstract}
ABSTRAK
Sumber energi terbarukan mempunyai sifat terbarukan serta berkesinambungan dan pemanfaatan sumber energi terbarukan merupakan alternatif yang perlu terus dikembangkan. Pembangkit Listrik Tenaga Surya (PLTS) menggunakan energi matahari sebagai sumber terbarukan dan mengkonversi energi matahari menjadi energi listrik. Untuk memaksimalkan intensitas matahari yang diterima oleh panel surya maka pada perancangan sistem dibutuhkan sudut kemiringan panel yang paling tepat untuk menerima radiasi matahari yang paling tinggi. Penelitian ini dilakukan untuk mengetahui peningkatan arus keluaran terhadap perubahan sudut kemiringan pada photovoltaic, dengan menggunakan regretion quadratic method. Hasil yang diperoleh pengukuran sudut kemiringan $P V$ dengan arus keluaran menggunakan metode regresi kuadratik sudut optimum peletakan panel sel surya dalam menerima paparan radiasi sinar matahari pada sudut $36.7^{\circ}$, dengan nilai arus keluaran sebesar 1.99 Ampere. Ternyata hasil pengukuran real dibandingkan dengan menggunakan metode regresi kuadratik diperoleh hasil nilai RMSE (root mean sequre error) 0.27476 .
\end{abstract}

Kata kunci: Photovoltaic, Sudut Kemiringan, Regresi Kuadratik 


\section{PENDAHULUAN}

Energi merupakan salah satu kebutuhan utama dalam kehidupan manusia. Namun permasalahan energi mulai timbul ketika kebutuhan akan energi untuk menopang pertumbuhan ekonomi berbagai negara justru membuat persediaan cadangan energi konvensional menjadi sedikit. Dalam pencarian sumber energi baru sebaiknya mempertimbangkan beberapa hal yaitu menghasilkan jumlah energi yang cukup besar, biaya ekonomis dan tidak berdampak negatif terhadap lingkungan [1]. Pencarian tersebut diarahkan pada pemanfaatan energi alternatif. Sumber energi alternatif ada saat ini Kebutuhan energi di Indonesia terus meningkat seiring dengan meningkatnya pertumbuhan penduduk, dan pertumbuhan ekonomi.

Pemenuhan kebutuhan energi listrik saat ini masih bergantung pada sumber energi fosil yang ketersediaanya terbatas. Oleh karena itu dimasa mendatang pemanfaatan sumber energi terbarukan merupakan alternatif yang perlu terus dikembangkan [2].

Sumber energi terbarukan mempunyai sifat terbarukan dan berkesinambungan. Pembangkit Listrik Tenaga Surya (PLTS) menggunakan energi matahari sebagai sumber energi terbarukan. Komponen utama dari PLTS adalah sel surya (sel photovoltaic). PLTS umumnya digunakan di daerah yang memiliki radiasi matahari yang tinggi dan daerah yang belum terjangkau oleh listrik PLN.

Kata 'photovoltaic' terdiri dari dua kata yaituphoto dan volta. Photo yang berarti cahaya (daribahasa Yunani yaitu phos, photos: cahaya) dan Volta (berasal dari nama seorang fisikawan italia yang hidup antara tahun 1745-1827 yang bernama Alessandro Volta) yang berarti unit tegangan listrik. Dengan kata lain, arti photovoltaic yaitu proseskonversi cahaya matahari secara langsung untuk diubah menjadi listrik. Oleh karena itu, kata photovoltaic biasa disingkat dengan PV. Photovoltaic merupakan elemen aktif (semikonduktor) yang memanfaatkan efek photovoltaic untuk mengubahenergi surya menjadi energi listrik tanpa penggunaan dari bagian-bagian mekanis yang bergerak dan tanpa penggunaan bahan bakar [3].

Indonesia merupakan negara yang terletak di garis khatulistiwa yang mempunyai tingkat radiasi harian matahari rata - rata yang relatif tinggi yaitu $4,5 \mathrm{kWh} / \mathrm{m}^{2} /$ hari [4]. Hal tersebut dapat digunakan sebagai modal utama pembangkitan listrik dengan menggunakan photovoltaic. Komponen utama dari sistem photovoltaic adalah sel surya yang berfungsi untuk mengkonversi energi cahaya matahari menjadi energi listrik.

Di Indonesia tipe sel surya yang banyak digunakan adalah tipe monokristalin dan polikristalin silicon, sedangkan jenis thin-film (lapisan tipis) masih sedikit pemanfaatannya.

Untuk memaksimalkan intensitas matahari yang diterima oleh panel surya maka pada perancangan sistem dibutuhkan sudut kemiringan panel yang paling tepat untuk menerima radiasi matahari yang paling tinggi. Sudut yang mempengaruhi pemasangan panel surya pada instalasi ada 2 macam yaitu sudut kemiringan panel surya terhadap bidang horisontal atau disebut juga dengan slope dan sudut yang diukur searah dengan acuan arah selatan yang disebut dengan sudut azimut. Ada beberapa parameter lingkungan yang dapat mempengaruhi kinerja dari sel surya, diantaranya, perubahan temperatur, intensitas radiasi matahari, tertutupnya sebagian permukaan sel surya (bayangan).

Dalam Jurnal yang berjudul Optimasi Sudut Kemiringan Panel Surya Pada Prototipe Sistem Penjejak Matahari Aktif yang diterbitkan pada Prosiding Seminar Nasional Fisika (E-Journal) SNF2016 Sudut kemiringan panel surya yang menghasilkan tegangan dan arus dalam jumlah yang lebih besar adalah pada sudut $10^{\circ}$ pada sumbu $\mathrm{x}$ negatif. Pada sudut kemiringan tersebut menghasilkan nilai daya yang paling maksimal sehingga pada sudut tersebut panel surya dapat bekerja optimal [5]. 
Dari latar belakang yang dipaparkan diatas maka panel surya tidak dapat menangkap pancaran sinar matahari secara maksimal sepanjang hari, akibatnya efisiensi energi listrik yang dibangkitkan tidak maksimal. Pada penelitian ini, peneliti akan merumuskan bagaimana pengaruh perubahan sudut kemiringan terhadap nilai arus keluaran dari photovoltaic. Penelitian dilakukan untuk mengetahui peningkatan arus keluaran terhadap perubahan sudut kemiringan pada photovoltaic, dengan menggunakan regretion quadratic method.

\section{METODE/PERANCANGAN PENELITIAN}

Dalam menyelesaikan penelitian ini, maka peneliti menggunakan beberapa tahap untuk menyelesaikan analisis pengaruh sudut kemiringan terhadap arus keluaran pada Photovoltaic terdiri dari :

- $\quad$ Studi literatur, yaitu mempelajari literatur-literatur dari jurnal-jurnal dan buku-buku teks yang relevan dengan penelitian yang akan dilakukan.

- Pengumpulan data dengan cara mengadakan pengamatan secara langsung terhadap objek kegiatan yang berhubungan dengan penelitian.

- Melakukan pengukuran pada Photovoltaic.

- Mengklasifikasikan data pengukuran yang telah didapat dari pengukuran di lapangan.

- Menganalisis pengaruh sudut kemiringan terhadap arus keluaran pada photovoltaic menggunakan regretion quadratic method.

\subsection{Alur Kerja Penelitian}

Alur kerja penelitian dapat dilihat pada bagan dibawah ini :

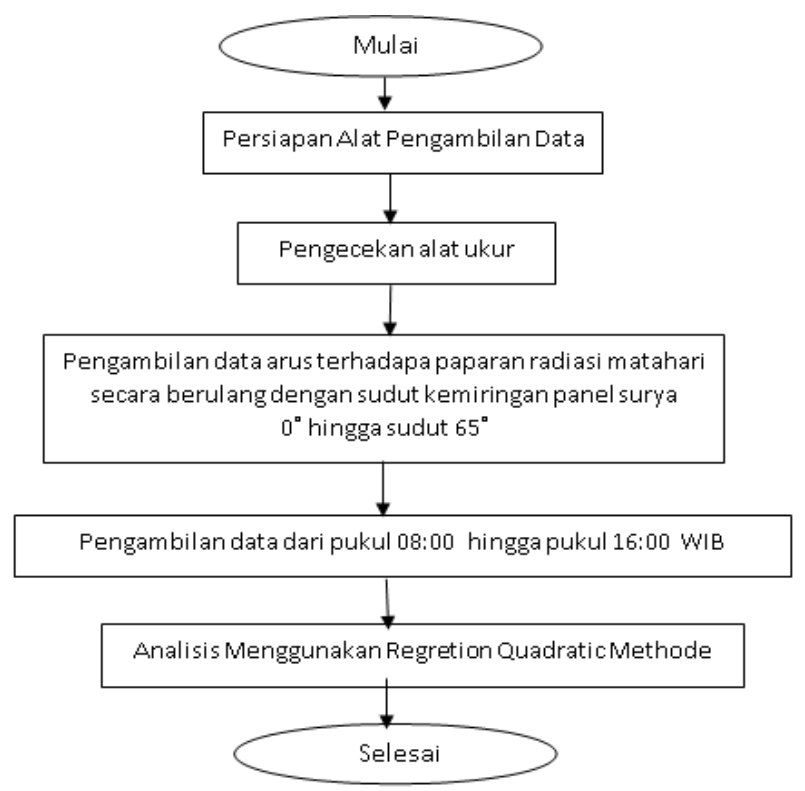

Gambar 1. Diagram alir penelitian

\subsection{Data Teknis Alat Ukur dan Peralatan yang di Gunakan}

Pengumpulan data dilakukan dengan mengukur tegangan, arus keluaran dan sudut kemiringan panel surya [6]. Dalam pengumpulan data yang dibutuhkan dalam penelitian ini digunakan beberapa peralatan sebagai alat ukur diantaranya: 
- Multimeter Digital

Digunakan untuk mengukur Ampere, Voltase, dan Resistansi. Dalam pengujian ini hanya dibutuhkan besarnya arus yang mengalir

- Kompas

Digunakan untuk menentukan arah penempatan modul surya yang diukur dari posisi sudut horizontal modul surya terhadap pergerakan matahari.

- Angel Meter

Digunakan untuk mengukur sudut pada panel surya.

- $\quad$ Alat Penyangga Panel Surya

Digunakan untuk menyangga panel surya

- Panel Surya

Panel surya yang digunakan adalah jenis Monocrystalline

- Solar Power Meter

Digunakan untuk menguji, mengukur intensitas energi surya

\section{HASIL DAN PEMBAHASAN}

\subsection{Arus Keluaran Dari Sebuah Modul Dalam Hubungannya Dengan Sudut Kemiringan}

Arus keluaran dari sebuah modul fotovoltaik bergantung pada besarnya radiasi surya yang diterima oleh modul. Keluaran total selama satu hari penuh dapat dihitung secara sederhana dengan mengalikan arus dengan waktu selama modul itu dikenai sinar matahari. Keluaran modul surya diberikan sebagai ampere jam per hari.

Dengan mengarahkan modul fotovoltaik pada kemiringan tertentu, radiasi surya yang diterima dapat dioptimalkan untuk suatu kurun waktu satu tahun. Yang selanjutnya hal ini akan memperbesar keluaran tahunan rata-rata modul fotovoltaik. Secara umum, kemiringan modul disesuaikan dengan posisi lintang lokasi penempatan.

\subsection{Pengaruh Sudut Kemiringan Pada Panel Sel Surya Terhadap Paparan Sinar Matahari}

Pada penelitian ini pengambilan data posisi/sudut panel surya terhadap matahari dilakukuan bertujuan untuk mengetahui seberapa besar arus keluaran pada selang waktu tertentu. Pengambilan data dilakukan dalam jangka waktu pukul 8.00 hingga pukul 16.00. Hasil yang didapat pada langkah ini digunakan untuk melihat dan menganalisa besar pergeseran arah panel surya setiap jamnya, karena proses perubahan sudut pada penelitian ini dilakukan pergeseran tiap jam.

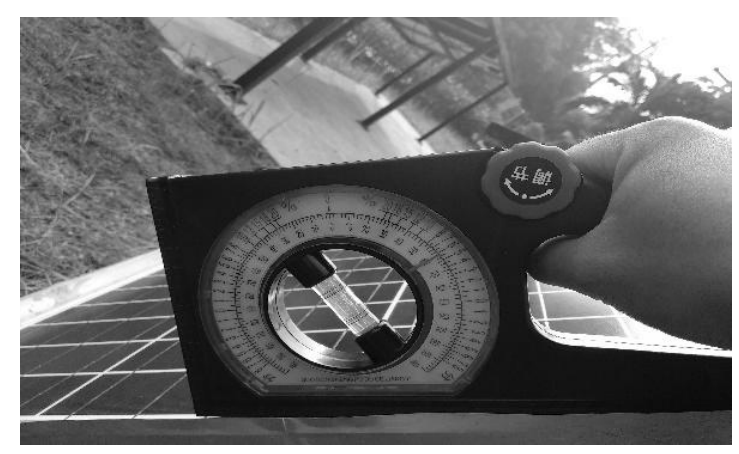

Gambar 2. Pengambilan data terhadap sudut panel pada sel surya 


\subsection{Pengaruh Sudut Kemiringan Panel Sel Surya Terhadap Arus yang Diterima Panel Surya}

Berdasarkan hasil pengambilan data selama 8 jam, dengan variasi sudut panel sel surya dari dari $0^{\circ}$ hingga sudut $65^{\circ}$ yang dilakukan tiap satu jam didapatkan nilai arus keluaran yang bervariasi dapat dilihat pada tabel 1 .

Tabel 1. Data sudut perubahan panel sel surya terhadap arus keluaran dari panel sel surya

\begin{tabular}{|c|c|c|c|c|c|c|c|c|c|c|c|c|c|c|}
\hline \multicolumn{15}{|c|}{ DATA ARUS (Ampere) } \\
\hline \multirow{2}{*}{ pukul } & \multicolumn{14}{|c|}{ SUDUT $\left(^{\circ}\right)$} \\
\hline & 0 & 5 & 10 & 15 & 20 & 25 & 30 & 35 & 40 & 45 & 50 & 55 & 60 & 65 \\
\hline $8: 00$ & 0.53 & 0.53 & 0.56 & 0.59 & 0.71 & 0.69 & 0.73 & 0.70 & 0.62 & 0.54 & 0.50 & 0.53 & 0.50 & 0.50 \\
\hline 9:00 & 1.43 & 1.45 & 1.49 & 1.63 & 1.65 & 1.59 & 1.50 & 1.29 & 1.29 & 1.21 & 1.11 & 1.07 & 1.01 & 0.97 \\
\hline 10:00 & 1.83 & 1.84 & 1.92 & 1.94 & 1.91 & 1.98 & 1.95 & 1.95 & 1.93 & 1.89 & 1.83 & 1.69 & 1.65 & 1.79 \\
\hline 11:00 & 1.38 & 1.38 & 1.34 & 1.26 & 1.31 & 1.27 & 1.23 & 1.31 & 1.32 & 1.45 & 1.33 & 1.57 & 1.58 & 1.54 \\
\hline 12:00 & 1.95 & 2.00 & 2.03 & 2.07 & 2.07 & 2.07 & 2.03 & 2.05 & 2.04 & 1.97 & 1.93 & 1.76 & 1.63 & 1.55 \\
\hline 13:00 & 1.40 & 1.62 & 1.57 & 1.88 & 1.08 & 2.02 & 2.07 & 2.05 & 2.04 & 2.00 & 1.91 & 1.89 & 1.10 & 1.60 \\
\hline $14: 00$ & 1.60 & 1.71 & 1.73 & 1.63 & 1.57 & 1.52 & 1.60 & 1.70 & 1.75 & 1.68 & 1.66 & 1.64 & 1.57 & 1.63 \\
\hline 15:00 & 0.85 & 0.83 & 0.86 & 0.85 & 0.86 & 0.84 & 0.57 & 0.83 & 0.81 & 0.73 & 0.57 & 0.76 & 0.72 & 0.66 \\
\hline $16: 00$ & 0.63 & 0.66 & 0.67 & 0.68 & 0.71 & 0.72 & 0.71 & 0.72 & 0.71 & 0.70 & 0.68 & 0.66 & 0.63 & 0.60 \\
\hline
\end{tabular}

Dari Tabel 1 dapat terlihat nila rata-rata arus keluaran panel sel surya selama 8 jam, nilai ratarata dari sudut $0^{\circ}$ sebesar $1.29 \mathrm{~A}$, sudut $5^{\circ}$ sebesar $1.34 \mathrm{~A}$, sudut $10^{\circ}$ sebesar $1.35 \mathrm{~A}$, sudut $15^{\circ}$ sebesar $1.39 \mathrm{~A}$, sudut $20^{\circ}$ sebesar $1.32 \mathrm{~A}$, sudut $25^{\circ}$ sebesar $1.41 \mathrm{~A}$, sudut $30^{\circ}$ sebesar $1.38 \mathrm{~A}$, sudut $35^{\circ}$ sebesar $1.40 \mathrm{~A}$, sudut $40^{\circ}$ sebesar $1.39 \mathrm{~A}$, sudut $45^{\circ}$ sebesar $1.35 \mathrm{~A}$, sudut $50^{\circ}$ sebesar $1.28 \mathrm{~A}$, sudut $55^{\circ}$ sebesar $1.29 \mathrm{~A}$, sudut $60^{\circ}$ sebesar $1.15 \mathrm{~A}$, sudut $65^{\circ}$ sebesar 1.20 A. Nilai rata-rata arus keluaran panel sel surya dapat dilihat dalam bentuk grafik pada gambar 2 .

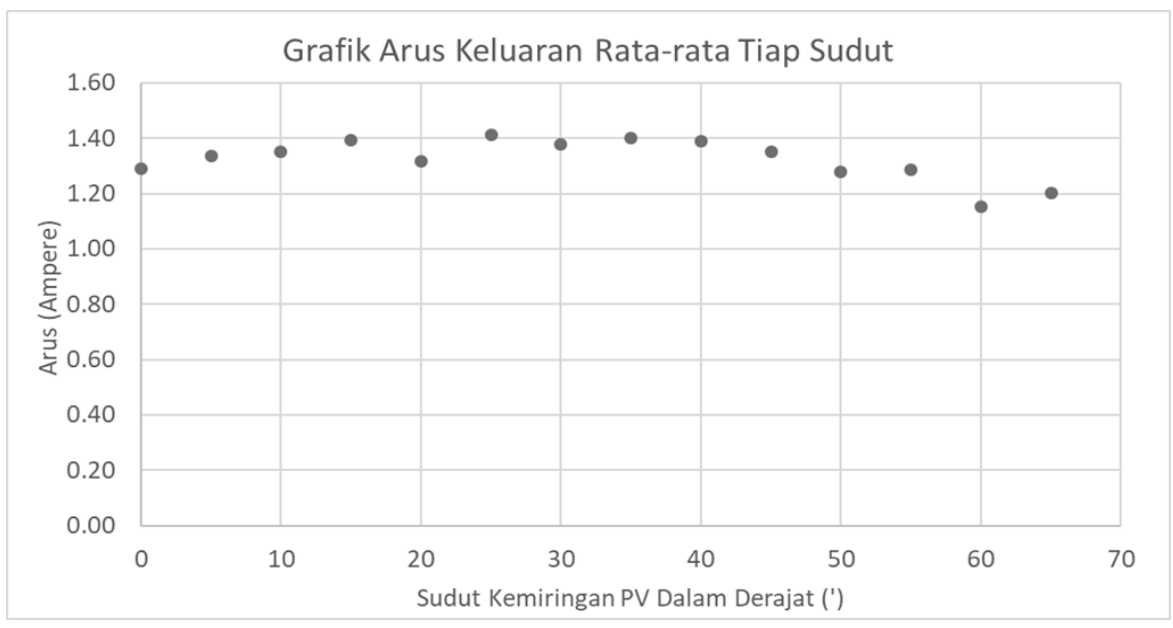

Gambar 2. Grafik Sudut keluaran rata-rata pada panel sel surya

\subsection{Analisa Regresi Kuadratik Sudut Kemiringan Terhadap Arus}

Dengan menggunakan data pada tabel 1 maka digunakan software excel sebagai alat bantu perhitungan dan analisa didapat persamaan regesi kuadratik polynomial. Adapun langkah untuk mendapatkannya dengan memasukkan nilai arus keluaran (y) dan sudut kemiringan PV (x), setelah memasukan variabel tersebut untuk mendapatkan grafik langkah selanjutnya dengan memilih insert 
dilanjutkan charts dan scatter. Untuk mencari persamaan regresi kuadratik polynomial dari variabel yang sudah dimasukkan, pilih tools design dilanjutkan add chart element trendline serta more trendline. Agar kita dapat menampilkan persamaan regresi kuadratik polynomial, langkah selanjutnya dengan memilih tools option polynomial serta memilih display equation in chart untuk melihat persamaan yang kita inginkan. Dari langkah tersebut diperolehlah sebuah persamaan regresi kuadratik polynomial. adapun persamaan berikut ini :

$y=-0.0005 x^{2}+0.0367 x+1.3184$

Persamaan regresi kuadratik polynomial disajikan dalam bentuk tabel 2 yang didapat dengan menggunakan software excel sebagai alat bantu menghitung.

Tabel 2. Persamaan Regresi Kuadratik

\begin{tabular}{|l|l|l|l|}
\hline & Intercept & $\mathbf{X}$ & $\mathbf{x}^{\wedge} \mathbf{2}$ \\
\hline Coefficients & 1.318428571 & 0.036669231 & -0.000532967 \\
\hline Standard Error & 0.210287404 & 0.015023227 & 0.000222842 \\
\hline t Stat & 6.269650703 & 2.440835762 & -2.391685377 \\
\hline P-value & $6.09031 \mathrm{E}-05$ & 0.032774116 & 0.035754653 \\
\hline Lower 95\% & 0.855589116 & 0.00360333 & -0.001023438 \\
\hline Upper 95\% & 1.781268027 & 0.069735131 & $-4.24959 \mathrm{E}-05$ \\
\hline Lower 95.0\% & 0.855589116 & 0.00360333 & -0.001023438 \\
\hline Upper 95.0\% & 1.781268027 & 0.069735131 & $-4.24959 \mathrm{E}-05$ \\
\hline
\end{tabular}

Persamaan regresi polynomial yang digunakan adalah dengan melihat grafik hubungan sudut kemiringan dengan arus keluaran pada pukul 13.00, hal tersebut dikarenakan pada waktu tersebut grafik regresi polynomial yang dihasilkan lebih baik yang artinya jika kita lihat secara grafik menyerupai bentuk polynomial mendekati sempurna. Berdasarkan langkah yang sudah dilakukan maka persamaan diatas serta grafik regresi kuadratik polynomial sudut kemiringan terhadap arus keluaran dapat dilihat pada gambar 3.

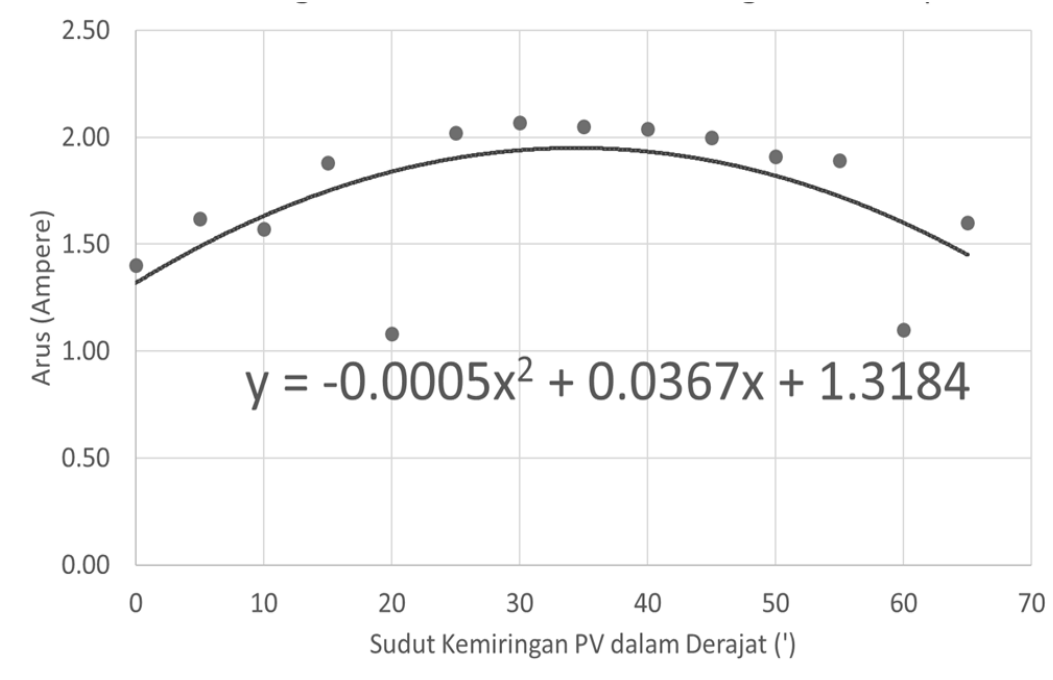

Gambar 3. Grafik Regresi Kuadratik Sudut Kemiringan Terhadap Arus 
Dari grafik gambar 3 menunjukan pada sudut kemiringan $0^{\circ}$ hingga $65^{\circ}$ membentuk grafik polynomial. Beberapa sampel sudut kemiringan PV dengan arus keluaran panel sel surya tertinggi yakni, pada sudut $30^{\circ}$, sudut $35^{\circ}$, dan sudut $40^{\circ}$, dari gafik gambar 6 terlihat jelas bahwa semakin besar sudut kemiringan, semakin turun pula nilai arus yang dihasilkan oleh panel sel surya, dan dapat dilihat pula bahwa semakin kecil nilai sudut akan berdampak pada penurunan nilai arus keluaran dari panel sel surya yang tidak terlihat signifikan.

Dan untuk menentukan sudut optimum peletakan panel sel surya dalam menghasilkan nilai arus keluaran tertinggi, dari persamaan regresi kuadratik polynomial yang sudah didapat sebelumnya. Optimasi langkah-langkah perhitungan dengan menurunkan persamaan 1 maka diperoleh :

$\mathrm{y}=-0.0005 \mathrm{x}^{2}+0.0367 \mathrm{x}+1.3184$

$\frac{d y}{d x}\left(-0.005 x^{2}+0.00367 x+1.3184\right)=0$

$2(-0.005 x+0.00367)=0$

$x=\frac{0.0367}{0.001}$

$x=36.7$

Dari penurunan persamaan tersebut maka didapat nilai sudut (x) sebesar $36.7^{0}$. Selanjutnya dengan mensubtitusi nilai $\mathrm{x}$ telah diperoleh, maka didapat besarnya nilai arus (y) sebesar 1.99 Ampere.

Untuk mengetahui akurasi dari pemodelan tersebut dibangkitkan nilai dugaan arus keluaran berdasarkan persamaan regresi.

$\hat{y}=-0.0005 x^{2}+0.0367 x+1.3184$

Dengan memasukan nilai sudut kemiringan (x) dari $0^{\circ}$ hingga $65^{\circ}$ didapatkan hasil seperti yang ditunjukan pada tabel 3 .

Tabel 3. Data Nilai Dugaan Arus Keluaran

\begin{tabular}{|l|l|l|l|}
\hline $\begin{array}{c}\text { Sudut } \\
\text { (Derajat) }\end{array}$ & $\begin{array}{c}\mathbf{y} \\
\text { Arus } \\
\text { (Ampere) }\end{array}$ & $\begin{array}{c}\text { Arus Dugaan } \\
\text { (Ampere) }\end{array}$ & y- $\hat{\boldsymbol{y}}$ \\
\hline 0 & 1.40 & 1.32 & 0.00666 \\
\hline 5 & 1.62 & 1.49 & 0.01706 \\
\hline 10 & 1.57 & 1.64 & 0.00428 \\
\hline 15 & 1.88 & 1.76 & 0.01528 \\
\hline 20 & 1.08 & 1.85 & 0.59660 \\
\hline 25 & 2.02 & 1.92 & 0.00933 \\
\hline 30 & 2.07 & 1.97 & 0.01012 \\
\hline 35 & 2.05 & 1.99 & 0.00355 \\
\hline 40 & 2.04 & 1.99 & 0.00287 \\
\hline 45 & 2.00 & 1.96 & 0.00181 \\
\hline 50 & 1.91 & 1.90 & 0.00004 \\
\hline 55 & 1.89 & 1.82 & 0.00430 \\
\hline 60 & 1.10 & 1.72 & 0.38490 \\
\hline 65 & 1.60 & 1.59 & 0.00007 \\
\hline
\end{tabular}


Selanjutnya dihitung RMSE (Root Mean Square Error) dari model regresi kuadratik polynomial menggunakan data pada tabel 3. RMSE adalah metode alternatif untuk mengevaluasi teknik peramalan yang digunakan untuk mengukur tingkat akurasi hasil prakiraan suatu model. RMSE merupakan nilai rata-rata dari jumlah kuadrat kesalahan, juga dapat menyatakan ukuran besarnya kesalahan yang dihasilkan oleh suatu model prakiraan. Nilai RMSE rendah menunjukkan bahwa variasi nilai yang dihasilkan oleh suatu model prakiraan mendekati variasi nilai obeservasinya [7].

Dengan menggunakan persamaan :

$R M S E=\sqrt{\frac{1}{n} \sum_{i=1}^{n}(y-\hat{y} i)^{2}}$

Dengan memasukan data-data pada tabel 3 menggunakan persamaan 2 maka, diperoleh hasil nilai RMSE 0.27476 dengan prosentase keakuratan sebesar $1.13 \%$, yang berarti nilai prosentase eror atau kesalahan menggunakan persamaan tersebut sangat kecil.

\section{KESIMPULAN DAN SARAN}

Berdasarkan penelitian yang dilakukan dapat disimpulkan bahwa hasil pengukuran sudut kemiringan PV dengan arus keluaran panel sel surya tertinggi yakni, pada sudut $30^{\circ}$, sudut $35^{\circ}$, dan sudut $40^{\circ}$, sedangkan dengan menggunakan metode regresi kuadratik sudut optimum peletakan panel sel surya dalam menerima paparan radiasi sinar matahari pada sudut $36.7^{\circ}$. Dengan metode regresi kuadratik polynomial untuk mendapatkan sudut optimum peletakan panel sel surya juga peroleh nilai arus keluaran tertinggi sebesar 1.99 Ampere. Dari hasil evaluasi yang telah dilakukan dengan menggunakan metode regresi kuadratik polynomial dibantu dengan software excel sebagai alat bantu dalam menganalisa, ternyata hasil pengukuran real dibandingkan dengan menggunakan metode regresi kuadratik diperoleh hasil nilai RMSE (root mean sequre error) 0.27476 dengan prosentase keakuratan sebesar $1.13 \%$, nilai $R M S E$ rendah menunjukkan bahwa variasi nilai yang dihasilkan oleh suatu model prakiraan mendekati variasi nilai obeservasinya.

\section{UCAPAN TERIMAKASIH}

Penulis mengucapkan terima kasih kepada STT PLN dan LP3M yang telah memberi dukungan yang membantu pelaksanaan penelitian dan atau penulisan artikel, semoga tulisan ini bermanfaat.

\section{DAFTAR PUSTAKA}

[1] A. Najmurrokhman and M. Fajrin, "Perancangan Prototipe Sistem Penjejak Matahari Untuk Mengoptimalkan Penyerapan Energy Surya Pada Solar Cell".

[2] APAMSI, Pengembangan PLTS di Indonesia, Yogyakarta, 2013.

[3] V. Quaschining, Understanding Renewable Energy Systems, London: Sterling, VA: Earthscan, 2005.

[4] M. Bachtiar, "Prosedur Perancangan Sistem Pembangkit Listrik Tenaga Surya Untuk Perumahan (Solar Home System)," SMARTek, vol. 4 No.3, pp. 176-182, 2006.

[5] T. S, I. W and B. Iswanto, "Optimasi Sudut Kemiringan Panel Surya Pada Prototipe Sistem Penjejak Matahari Aktif," Prosiding Seminar Nasional Fisika, vol. V, pp. 53-56, 2016.

[6] A. W. Duffie and W. A. Beckman, Solar Engineering of Thermal Process, Newyork: Jhon Wiley \& Sons, 2008.

[7] S. Makridakis, "The Accuracy of Extrapolative (Time Series Methods) Result of Forecasting Competition," Journal of Forecasting, vol. 1 No 2, pp. 111-153, 1982.

[8] BMTI, ET Pengenalan Teknologi PLTS, Bandung, 2008. 